\title{
Analysing the contribution of the product offerings to the customer satisfaction of co-operative Bank. A case study
}

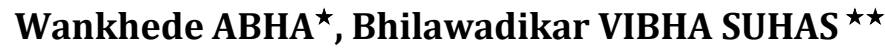

\begin{tabular}{l} 
A R T I C L E I N F O \\
\hline Article history: \\
Accepted December 2018 \\
Available online April 2019 \\
\hline JEL Classification \\
G21 \\
Keywords: \\
Cooperative banks, Customer \\
satisfaction, Product offerings, \\
Product features, Business growth, \\
Customer centric
\end{tabular}

\begin{abstract}
A B S T R A C T
As the banking industry is evolving the role of cooperative banking needs to be understood more closely. These institutions are pillars of financial stability and inclusiveness. However, since the market is opened it becomes imperative for these banks too to assess customer satisfaction and ensure strong relationship with their existing customers. This research among the current customers of Vishwas cooperative bank highlighted the contribution of product offering to the concept of customer satisfaction especially in the times when being customer centric is considered imperative for being successful in business. Ease of getting loans and to acquire credit facilities from the Bank was the key factor that influenced the customer satisfaction positively.
\end{abstract}

(C) 2019 EAI. All rights reserved.

\section{Introduction}

Cooperative banking has been existing since 19nth century in India but despite being present in the economic system for a long time only very recently serious attention to these institutions have been given considering the potential of these institutions to become the integral part of the developmental pillar of any economic system especially for emerging economies like India and China. This is also because cooperative banks in India have contributed to meeting the financial requirements of $50 \%$ of India's total population in the recent past (http://www.businessworld.in/article/50-Of-Indians-Are-Associated-With-Cooperative-Banks/1108-2017-123939/).The dominant aim of these institutions has always been to help in channelizing the idle human and green energies of the society and converting them into a fruitful venture for the purpose of financial empowerment of the masses. Apart from channelizing the idle savings these institutions help in the development of small \& medium scale enterprises in urban and rural areas by providing substantial credit facilities. In this era of globalization, the researchers believe that cooperative banks are going to play a unique role due to its ownership pattern and its ability to mobilise small savings especially from rural population. Any globally aligned emerging economies are vulnerable to adverse impact due to liberalized and free economic system and these effects will be neutralized due to the unique characteristics of these institutions to reach large populations in the remote corners of the economies and embark upon the financial goals of inclusion and stability. (Dr. Vibha Bhilawadikar's Doctoral Thesis "Impact of Personal Intervention on business relationships in banking sector: 2017)

Keeping in view India's growing integration with global financial markets, external-sector vulnerabilities have an increasingly large impact on India through the trade and capital account channels. It is therefore important that the development of an efficient and healthy financial market should also be accompanied by an effective regulatory mechanism that keeps track of all the vulnerabilities and maintains a balance between the financial inclusion, financial vibrancy and financial stability.

In any programme of social and economic change, cooperative movement has a relevance and importance, and this has been immensely proved in the history. Economic development along democratic lines offer vast field of application of cooperative principles of management across different sectors. It is seen that only through cooperative institutions can the common man influence the direction of change and economic development in a desired direction.

This is because cooperative movement represents the institutionalization of principles and mutual aid combining with freedom and opportunity for the common man to bring the desired socio-economic change in the country and community. It uses the potential of people and principles of capitalism to create the necessary magic in the economic system. (Bhagwati Prasad, December 2005). 
The banking sector was thrown open to international competition and privatization in 1992 leading to a lot of competitive pressures in retail banking. To make matters worse in this sector the marketers encountered the hard reality of multiple banking relationship at any given time. On this backdrop of fierce competition, the banking industry too like other companies across industry sectors started looking at driving their marketing strategy using customer satisfaction, customer retention and customer loyalty as key business metrics. These metrics made organisations focused on customer's expectations and associated performance on these expectations from organisations. But due to multiple banking relationships, in this business when the customer is interacting with the bank it is comparing the experience with their own expectations and also comparing the service experience offered by other banks. It is not surprising therefore that it is immensely important to strengthen the relationship with the current retail customer using banks own strengths and product offerings which is an ensemble of product features and services is one such strength that can offer an enhancing experience. Product offerings comprise of many dimensions such as price-value equation, image, and channel touch-points in addition to the basic banking product itself. Further banking is a complex product and it is consumed as it is offered so although product offering is one of the strong pillars in contributing to customer satisfaction, it is important to understand the extent of its contribution towards this key business metrics and key parameters that constitute to help forge strong relationships with the customers. A strong product offering which is ensemble of product and services and the associated service quality can drive high level of convenience, trust and confidence in the mind of the customer in this business leading to strong customer satisfaction (Ruth N Bolton, 1998). However, the dynamics of product offerings is changing. A study on Customers Perception of Service Quality in Indian Banks written by Arun Kumar Panda and Saroj Kumar Dash, it is highlighted that in the past bank customers were easy to handle and manage. Customers were happy at whatever the banks offered to them as a service like the bank clerk smiling or greeting etc. Over a period of time with competition and technological improvements customer have become fully aware and informed of their rights and the benefits that they should be getting in any business set up and dealing with a knowledgeable customer is becoming tougher and tougher. Achieving and maintaining a commanding position in the market place is becoming increasingly difficult in a wide variety of businesses on these grounds creating a landscape of buyer market and a higher buyer bargaining power. It is extremely difficult in the banking organizations too. Given below is the focus of marketers in this sector:

Table No. 1: (Arun Kumar Panda and Saroj Kumar Dash2012) as written by the authors:

\begin{tabular}{|l|l|}
\hline \multicolumn{2}{|c|}{ Presenting the Changes in the customer Focus over the Decades } \\
\hline Decade & Focus on the Customer \\
\hline $1950-1960$ & Serving the Customer \\
\hline $1960-1980$ & Satisfying the Customer \\
\hline $1980-1990$ & Pleasing the Customer \\
\hline $1990-2000$ & Delighting the Customer \\
\hline 2000 and beyond & Retaining the Customer \\
\hline
\end{tabular}

Lately bank services have transformed and have developed into new hybrid services which are traditionally non-banking products such as being distributors for insurance and mutual funds or advising between different funds etc and all these services are offered over and above the core banking product. Additionally, the banks also offer many different service channels to service the customers. The reason for all this is "value proposition" and also product offerings have become product features and services continuum (Arun Kumar Panda and Saroj Kumar Dash 2012). When a service is offered to a customer across the abovementioned different transactions and service channels basically it is delivering service value while consuming the key banking service. It is felt that the interaction with the product features and services leads to building of the trust and the confidence among the customers leading to the three important metrics that measure the business health i.e. Customer Satisfaction, Customer Retention and Customer Loyalty (Gutek Barbara, A. Groth and Cherry Benneth, 2002). Clearly it highlights that in a service relationship, the two individuals, the provider and the customer have repeated contact with each other and over time they get to know each other very closely and sometimes even become friends.

At another level when the same service is offered at the expected speed, prices and other such conveniences then there is a high chance of the organisation becoming the preferred choice in this business. This is because there is a tendency of increased awareness at the customer's level to use service by comparing between service qualities that they get with the cost that they should be paying. Therefore, the organizations pay a lot of attention to consumer preference on the value offered when making a customer 
centric marketing strategy and similarly customers also take conscious decisions about who they choose as their financial partners in any banking relationship (Peter C. Verhoef, October 2003).

It is also seen that this service can easily be copied and so it becomes difficult to retain the customer. On this backdrop the product offering is also meshed with emotional bonding so that the product appreciation by the customer which is in its initial stages itself can be treated as a first feeling of vital connection to retain the customers with the bank because it transfers the core value of trust and confidence.

Thus, the concept of value in the service delivery from the financial organization is dynamic and it is felt that it will be ever evolving given the nature of service, i.e. this is a service of consumption relationship between the two entities. This paper attempts to evaluate the relationship of product features/offerings with these three metrics collapsed into one key metric which is 'customer satisfaction' in a cooperative banking set up.

\section{Literature review \\ Banking \& Customer Satisfaction:}

Financial services as a product is difficult to understand as it is layered by too many service elements too and because of its regulatory regime in most occasions the service is about validating the very basic documentary requirements making a lot of customers uninvolved or irritable in this service category. Banking business is thus in a regulatory context and under such business circumstances there is a possibility of potential losses due to service failure or short delivery in certain service interactions due to tacit, nonverbal behaviour or technical reasons.

To make the business context very sensitive the product that it is handling i.e. the money and management of money is crucial and important subject matter touching all facets of human life. Probably it is one of the important commodities that can cause maximum personal stress if not handled intelligently. Thus, service providers in this context are selling their offerings that do impact and touch customer's lives at a very personal level sometimes at a very soul level. In many ways' money defines who the person is: what is his life and how he wishes to plan the same around money and what opportunities it can provide for them to make it easy and a lively wonderful experience. For example: the type of housing the consumers choose, the type of clothing they wear, the school's children attend, vacations and retirement plans all are structured and expressed using money. It thus is an emotional matter and any short deliveries on returns or application of the money can cause a lot of mental emotional and physical trauma (https://www.fastcompany.com/28699/money-and-meaning-life).

Thus, product features matter a lot in this business and will have a considerable impact on the overall customer psyche and overall customer satisfaction which is embedded with the concept of being retained and loyal to firm or the brand. There are many examples of irrelevant service features being offered all the time in the business for example offering "free movie tickets" to a non-goer of cinema or a free valet parking service for a high net worth customer who enters the bank premise for that one-off bank premise interaction in a chauffeur driven car. These irrelevant features can cause more angst than customer delight as pointed out by the model, developed by Japanese quality expert Dr. Noriaki Kano that describes the complexities of customer needs and their relationship to customer satisfaction.

Thus, attention to customer needs that are stated and latent but as valued by them need to be understood and delivered. This definitely can lead to higher satisfaction because of the service experience and a big predictor of satisfaction. Companies will need to continue to measure the value of products features because they are not only changing but are based on the perceptual quality as perceived by customers as the experience is getting consumed. And this perceived quality specifications have moved on from being merely engineering/technical specifications in across all the industries.

To amplify the above mentioned thought it is important to point out that traditionally, mainstream focus was always on manufacturing sector. There were a lot of articles published in the inaugural issue of Marketing Science in 1982 that focused on product features. So earlier marketing science focused on sales analysis, product design for the determination of the optimal set of attributes etc. as compared to the recent move towards "design thinking which is customer centric". Earlier expenditures too were by product and the optimal marketing mix determined product strategies and not by customer needs or expectations. As compared with older journals, a lot of articles in the new journals are now focusing on customer behavior, customer retention or understanding customer relationships etc. Newer research in marketing science also attempts to find out the neurological responses of the customers to stimulus, or are giving more importance to customer likes, dislikes and preferences (Roland. T. Rust, Tuck Sion Chung, November 2006).

Banking too as competition increases needs to make very tailored and differentiated product offering by understanding what is it that customer values. Because of the recession and the scandals in the banking industry in recent year's customer confidence has been shaken up. In 2010, J. D. Power and Associates conducted a satisfaction study in the United States about products and services in retail banking using 48,000 retail banking customers and it was revealed that the majority of customers change banks because of poor customer service (J.D. Power, 2011). Michael Beird of the financial sector at J. D. Power and Associates concluded as loyalty declines, attention must address to the basics of service such as greeting customers and 
maintaining a branch (J. D. Power, 2011). All the above points towards being customer focused on product features.

Overall the significance of customer satisfaction cannot be dismissed and while happy customers are like free advertising it is felt that the measure still reflects only the transactional measures. So, it is necessary to put the customer at the centre of the business according to its product strategies and business processes to ensure a good customer experience that will drive higher customer satisfaction. In fact, it is always said that it is easier and more profitable to sell to current customers than to find new ones and a good experience will only ensure this business reality. Organizations thus are setting themselves customer retention targets as their next level goal for all the current customers. And the most important goal that companies consider is to enhance customer loyalty to the firm or the brand (Gutek Barbara, A. Groth and Cherry Benneth, 2002). In order to accomplish these three goals companies always focus more on customer centric approaches in their organizational and marketing strategies (Jain and Singh, 2002). The researchers will thus present a six variable construct to build evidence around the three goals mentioned above.

\section{Cooperative Banking \& Customer Satisfaction:}

India is progressing, but this progress cannot be lopsided. Privatization of the banks, multinational banks do not have the natural trait of exploring the human potential of India that lives in the remotest corner. It is here that the importance of these banks come to the fore. Cooperative banking system will activate the participation of rural population into the financial system leading to a very balanced growth path for the economy.

While this is a reality it does not give the cooperative banks the luxury of not measuring customer satisfaction because this same rural/semi-urban consumer too is banking and dealing with different banks. Hence measuring customer satisfaction even in case of cooperative banking set up is necessary. The doctoral research experiment conducted by Dr. Vibha Bhilawadikar identified this requirement and had set up this experiment on the backdrop of cooperative banking.

This literature review thus guided to formulate the overall product offering and satisfaction concept and lead to the contribution of the same in the metric of customer satisfaction.

\section{Cooperative Banking \& Overall Product offering:}

Consumer expectations change as per times. Thus, it is important to build a consumer centric model even when the bank is dealing product offering. With this thought in mind the researchers conducted qualitative study to build the consumer expectations into the product offering (Thorsten, Hennig, Kevin.Gwinner, 2000).

This intervention was conducted at three levels.

1. The banking product across banks were reviewed to build the product concept.

2. Internal stake holder interviews were conducted to find out the real time on ground product offering.

3. Discussions with the customers were conducted to understand their expectations and these too were built into the product offering.

\section{Research Problem Statement}

This study is conducted to understand the relative contribution and significance of product expectations on the key business metric that is customer satisfaction. In the current competitive banking industry customer satisfaction is a function of the of banks product offerings, its image, price (cost borne by the customer for getting his banking needs serviced), Bank's service aspects such as the service provided by the customer facing bank employee (personal banker/teller), ambience (infrastructure of the Bank) and the technology used by the bank to reach and provide access to the customer for all his/her banking needs (https://www.nbrii.com/customer-survey-white-papers/measuring-and-managing-customer-satisfaction/).

The scope of this paper is to study the contribution of the product offerings by the bank to customer satisfaction and identify the key factor which is the influencer and motivator of customer satisfaction.

\section{Research Design and Methodology}

A qualitative research was conducted through in-depth interviews of the ten-high net-worth customers of the Bank to understand the construct of Product features/offerings and Customer satisfaction. This was followed by a quantitative research survey by administrating a structured questionnaire and capturing the responses on a 10-point Likert scale of 500 existing current customers of the Bank. Nonprobability convenience sampling method was adopted.

Instrument validity was checked using Factor Analysis, Reliability using Cronbach's Alpha, and Descriptive statistics to describe the demographic profile of the sample which represents the population of this study. The results of the survey were analyzed using a multivariate regression analysis.

The experiment is set in the context of Vishwas Cooperative Bank and the attempt is to establish the analytical connection between the concept of product offering/features and the definition of customer satisfaction that is 
implicitly pointing towards customer retention and loyalty too. The time honored concept of product orientation is picked up and using customer's lens and the latest paradigm of customer relationship marketing the product features are defined. Since it is about current customers' retention and loyalty towards the bank this study is conducted among current customers who considered this bank as their primary bank. The information was elicited using qualitative and quantitative techniques of marketing research.

\section{Variables}

Building of the variables in the key end outcomes or business metrics and product feature expectations was also a process of discovery in this research. So, an enquiry into the concept of customer satisfaction, customer retention and customer loyalty in addition to expectations from the product was initiated to develop the variables and build the key variables that is forming an emotional equivalence of wellness or an attitude in the mind of the customer with respect to the concepts of product and customer satisfaction

\section{Independent variables}

Product quality which is denoted by features that get bundled together are central for delivering service in this business and therefore it is the key driver of customer satisfaction. The trust and confidence in banks have been declining due to many scandals worldwide and in that context, it is important for bank leaders to understand the customer needs and requirements and bundle them up in the product features across all the bank products. The following statements emerge out of the expectations expressed by the customers at an overall product level. Here the bank name therefore is the brand name.

\section{Table 2}

\begin{tabular}{|l|}
\hline Product Features \\
\hline BANK has a wide range of savings, deposit and investment products to suit my needs \\
\hline BANK helps me protect and grow my financial well being \\
\hline BANK has a range of attractive Loans and Credit facilities that suit my particular requirements \\
\hline I find it easy to get loans and acquire credit facilities from BANK \\
\hline $\begin{array}{l}\text { There are many channels of BANK (like Branch, ATM, Internet Banking etc.) makes banking } \\
\text { with them convenient }\end{array}$ \\
\hline $\begin{array}{l}\text { I find it easy to carry out all my regular transactions with BANK like making payments, } \\
\text { withdrawing cash }\end{array}$ \\
\hline The bank has products that are easy to understand \\
\hline The more products I hold with BANK, the better rates I receive \\
\hline The more products I hold with BANK, the better services I receive \\
\hline The bank has products that suit my business and personal needs \\
\hline $\begin{array}{l}\text { Availability of all transaction services that you need such as deposit, money withdrawal, fund } \\
\text { transfers, setting up designated account for utility payment etc. }\end{array}$ \\
\hline Overall Product Satisfaction \\
\hline
\end{tabular}

\section{Dependent Variables}

Interestingly the discussions with the Vishwas Cooperative bank customers revealed that in each of the key metrics the underlying stated need was "to continue to be connected and doing business with the bank". So, a six-parameter construct is created to represent customer satisfaction.

Table No.3

Definition of Key Metric:

\begin{tabular}{|l|ll|}
\hline \multicolumn{1}{|c|}{ Key Metrics } & \multicolumn{1}{c|}{ (measured on a ten-point scale) } \\
\hline Customer Satisfaction as a strong & 1. & \multicolumn{1}{|c|}{ Overall satisfaction with current transaction } \\
positive emotional feeling for the & 2. & Continue to bank with this bank \\
bank. (6 items) & 3. & Buy more products and services from the banks \\
& 4. Expand relationship \\
& 5. Overall satisfaction across all transactions \\
& 6. & Recommend the bank to friends and colleagues \\
\hline
\end{tabular}

(Dr. Vibha Bhilawadikar's Doctoral Thesis On "Impact of personal intervention on business relationships in banking sector 2017). 


\section{Instrument Validity}

Instrument validity using Factor analysis *Kaiser Mayer Olkin (KMO) statistics was used to examine the appropriateness of factor analysis. Value greater than or equal to 0.5 were considered as acceptable. Bartlett test of sphere-city was used to test the whether the items defining the construct are un-correlated (Malhotra, N.K.2011. Marketing Research.

Table 4

\begin{tabular}{|l|l|r|r|}
\hline & & \multicolumn{2}{|l|}{$\begin{array}{l}\text { Customer } \\
\text { Satisfaction }\end{array}$} \\
\hline \multicolumn{2}{|l|}{$\begin{array}{l}\text { Kaiser-Meyer-Olkin Measure of } \\
\text { Sampling Adequacy. }\end{array}$} & 0.921 & 0.817 \\
\hline $\begin{array}{l}\text { Bartlett's } \\
\text { Test of } \\
\text { Sphericity }\end{array}$ & Approx. Chi-Square & 3556.361 & 2514.456 \\
\cline { 2 - 5 } & Df & 21 & 15 \\
\cline { 2 - 5 } & Sig. & 0.000 & 0.000 \\
\hline
\end{tabular}

All the factors of customer satisfaction loaded on one factor. The above statistics of Product features is after the product items number firth (There are many channels of the Bank) and sixth (I find it easy to carry out all my transactions) were dropped as they loaded on other factor. After that all the factors of Product features loaded only on one factor.

Bartlett test of sphere-city is significant as $\mathrm{p}$ value is less than 0.05 and KMO value is greater than equal to 0.5 , we infer that the items used to define the variables are valid.

Table 5. Independent variables

\begin{tabular}{|l|}
\hline Product Features \\
\hline 1) BANK has a wide range of savings, deposit and investment products to suit my needs \\
\hline 2) BANK helps me protect and grow my financial well being \\
\hline $\begin{array}{l}\text { 3) BANK has a range of attractive Loans and Credit facilities that suit my particular } \\
\text { requirements }\end{array}$ \\
\hline 4) I find it easy to get loans and acquire credit facilities from BANK \\
\hline 5) The bank has products that are easy to understand \\
\hline 6) The more products I hold with BANK, the better rates I receive \\
\hline 7) The more products I hold with BANK, the better services I receive \\
\hline 8) The bank has products that suit my business and personal needs \\
\hline $\begin{array}{l}\text { 9) Availability of all transaction services that you need such as deposit, money withdrawal, } \\
\text { fund transfers, setting up designated account for utility payment etc. }\end{array}$ \\
\hline 10) Overall Product Satisfaction \\
\hline
\end{tabular}

These statements were then evaluated on a 10-point scale where 1 was poor and 10 was excellent.

\section{Hypotheses}

H1: Banks having wide range of savings, deposits and investment products will influence positively on customer satisfaction.

H2: Banks who are perceived by their customers to protect and grow their financial wellbeing influences the customer satisfaction of their customers positively.

H3: Banks having a range of attractive Loans and Credit facilities will influence positively in the customer satisfaction.

H4: Banks which are perceived by their customers to have easy loans and credit processing facilities influence the customer satisfaction positively.

H5: Banks designing products that are easy to understand by their customers influences the customer satisfaction positively.

H6: Giving better price deals to customer who buy more products influences the customer satisfaction positively.

H7: Giving better service to customer who buy more products influences the customer satisfaction positively.

H8: Banks which are perceived to have products that suit the customers business and personal needs by their customers influence the customer satisfaction positively.

H9: Banks having availability of all transaction's services influence their customer satisfaction positively. H10: Customers overall product satisfaction also influences their overall satisfaction with the Bank positively. 


\section{Empirical Results}

Demographic profile:

Descriptive statistics of the respondents is the representation of the customers of the Bank. Almost $18 \%$ are very young between the age group of 25 to 29 years. $40 \%$ are above 30 and less than 45 years of age. $20 \%$ are above 45 years and less than 55years and a good big chunk $18 \%$ above 55 years of age. Almost three fourth of them did not want to disclose their household income. The remaining one fourth of them who revealed their household income, $29 \%$ had a monthly household income between 15 to 25 thousand rupees and another $28 \%$ had 25 to 50 thousand rupees. $13 \%$ had less than 15 thousand as monthly as monthly income. Interestingly $80 \%$ of the customers are women and rest are men. $39 \%$ of the customers are graduates, and an equal number of them $39 \%$ have do not have qualification above $12^{\text {th }}$ grade. $15 \%$ are post graduates. $2.3 \%$ are PhDs. Occupation wise almost $47 \%$ of customers were managing their own small business and few were involved in trade. $34 \%$ are serving in private enterprise and only $10 \%$ were serving in the government sector.

Reliability Test - CronBachs'Alpha
\begin{tabular}{|l|r|r|}
\hline & Table 6 \\
\hline & Cronbach's Alpha & N of Items \\
\hline Product & 0.957 & 10 \\
\hline Custoemr Satisfaction & 0.906 & 6 \\
\hline
\end{tabular}

The Cronbach's Alpha scores show consistency among the number of items built to collect the actual results. All the values of all the variables are inclining to 1 . The scale is reliable.

\section{Model Fit}

Regression analysis (Malhotra, N.K.2011. Marketing Research).

Table 7 Multiple Regression Model Summary

\begin{tabular}{|l|l|l|l|l|lr|}
\hline Model & & R & R-Square & Adjusted R-Square & Standard Error of Estimate & 0.65079 \\
\hline & & 0.511 & 0.261 & 0.248 & \\
\hline & $\begin{array}{l}\text { Predictors - (Constant), Prod10, Prod 9, Prod 5, Prod 4, Prod1, Prod 7, Prod 6, Prod 2, Prod 8, } \\
\text { Prod3 }\end{array}$ \\
\hline
\end{tabular}

$\mathrm{R}$ value is 0.511 , which indicates the correlation between the Customer Satisfaction and its predictors of the Product Offerings. Rsquare (coefficient of determination) value is 0.261 , infers that percentage of variance of Customer Satisfaction of the customers of the Co-Operative Bank studied in this case with the product offered by the Bank to its customers. This answers our question that only $26.1 \%$ is the contribution of prediction of Customer Satisfaction by the Product offerings of the Bank.

Table 8 Analysis of Variance

\begin{tabular}{|l|r|r|r|r|r|}
\hline Model & Sum of Squares & \multicolumn{1}{l|}{ DF } & Mean Square & F Statistics & Significance \\
\hline Regression & 81.271 & 10 & 8.127 & 19.189 & .000 \\
\hline Residual & 229.976 & 543 & 0.424 & & \\
\hline Total & 311.247 & 553 & & & \\
\hline
\end{tabular}

Analysis of Variance gives p-value of less than 0.1 , which indicates model fit. The model results in a significant good degree of prediction of the dependent variable, the Customer Satisfaction.

Table 9 Coefficients, Dependent Variable- Customer Satisfaction

\begin{tabular}{|l|l|l|l|}
\hline Model & Co-efficient & $\mathrm{t}$ & Significance \\
\hline Constant & 5.81 & 22.54 & 0.00 \\
\hline Prod1 & 0.00 & 0.02 & 0.99 \\
\hline Prod2 & -0.01 & -0.24 & 0.81 \\
\hline Prod3 & 0.04 & 0.78 & 0.44 \\
\hline Prod4 & 0.09 & 1.87 & 0.06 \\
\hline
\end{tabular}




\begin{tabular}{|l|l|l|l|}
\hline Model & Co-efficient & $\mathrm{t}$ & Significance \\
\hline Prod5 & 0.00 & 0.07 & 0.94 \\
\hline Prod6 & -0.01 & -0.22 & 0.83 \\
\hline Prod7 & 0.07 & 1.46 & 0.14 \\
\hline Prod8 & 0.00 & -0.08 & 0.93 \\
\hline Prod9 & -0.04 & -1.27 & 0.21 \\
\hline Prod10 & 0.24 & 4.43 & 0.00 \\
\hline
\end{tabular}

The factors that contribute mainly to the Customer Satisfaction are P4 and P10 as the p-value is less than 0.1 . The constant has p-value less than 0.1 , so it is significant in this case.

Table 10 Inference

\begin{tabular}{|l|l|l|}
\hline Hypothesis & p value & Inference \\
\hline H1 & 0.99 & Reject \\
\hline H2 & 0.81 & Reject \\
\hline H3 & 0.44 & Reject \\
\hline H4 & 0.06 & Accept \\
\hline H5 & 0.94 & Reject \\
\hline H6 & 0.83 & Reject \\
\hline H7 & 0.14 & Reject \\
\hline H8 & 0.93 & Reject \\
\hline H9 & 0.21 & Reject \\
\hline H10 & 0.00 & Accept \\
\hline
\end{tabular}

\section{Discussions, Implications \& Direction for future research}

At a macro level, expansion of banking system can accelerate the growth of an economy is a well accepted fact. Cooperative banking system is an important constituent of the banking system in Indian economy is also not debated.

Product offering is one of the strongest pillars and contributes $26 \%$ to the customer satisfaction concept. Given this level of impact, it is only crucial to ensure that there are no short deliveries or complete service failures in this case.

These institutions can bring in the necessary financial liquidity and stability to the country is a reality as it caters to masses who lead their daily lives by running small businesses. Thus, to energise these business systems it is important for these institutions to offer those products and services that are relevant to their customer base. This research explores the contribution of product offering and focuses on making the product offering as relevant as is possible to customer expectations. The qualitative study brought out the all the product features and further deep dive analysis unearthed the fact that Banks offering attractive loans and credit facilities is the key influencer and motivator for customer satisfaction. Demographic descriptive statistics suggest that most of the customer, $80 \%$ of them are women and $47 \%$ of the managing their small business and trade. This indicates that in the small towns and rural areas the co-operative banks can have a long term and loyal customer base if they continue to focus on this product offering of easy credit facility and smooth loan processing. It can be observed that overall product satisfaction also influences the customer satisfaction positively, but if the same product features are evaluated separately and independently they are not the predictors and have no positive influence, which conjectures that the customer considers the other product features as hygiene factors and expects these basket of offerings as essentials, an absence of them will lead to dissatisfaction, but the presence of them are the necessary conditions that they expect from the Bank.

Many cooperative banking set ups do not measure these metrics on a periodic basis as they feel they have their ground to the ear when it comes to the customers. But in these times when the multiple banking is a reality it is important to engage the customer more and not allow the customer to move to any other bank. A programme of measurement in this area will ensure customer retention and expansion strategies for cooperative banks. (https://www.marketingmag.com.au/hubs-c/banking-sector-challenges-fintechdisruption-falling-customer-experience-ratings/)

Since attracting new customers is also an important feature for business growth, it is recommended that the bank must put their best foot forward to attract new customers using the credit facilities that the 
bank is so popular for among the prospective customers. They can differentiate themselves on this product features and chalk out the positioning and marketing communication strategy to be perceived in the same fashion by their target customers. Relationships with all the current customers too could be expanded using these credit-based products.

The very operating mechanism of cooperative banking is the structure of offering easy loans and credits to small borrowers. It is evident that this banking structure is the life line to not just a vast current and potential customer base of any cooperative bank, but overall Indian population given that Indian population is still living in rural India and running their life's livelihoods through small loans. Easy credit delivery to its shareholders or members is probably the most profitable way to grow the bank followed by overall product satisfaction which is a sum of all the product features that the model has thrown up as important features.

Customer satisfaction as a business metric if is measured diligently by these banks on a periodic basis will not only build a lot customer orientation in the product features leading to strategies emerging out of customer expectations but will also help these set-ups to compete effectively with other private and public sector banks. This will also give a much-needed transparent structure to this system of banking and give them the competitive advantage to capitalize on their core strengths in this highly competitive landscape. (https://blog.hubspot.com/service/customer-satisfaction-metrics)

This deep dive analytical analysis into product offering features to customer satisfaction does pave a way to explore the contributions of other remaining three P's VIZ Price, Place and Promotion constructs into the concept of customer satisfaction.

At an overall it is evident that this type of banking structure still is like lifeline to a vast urban and rural population in terms of providence of banking facilities to masses and small business men/women.

\section{Conclusions}

Cooperative banking system will remain relevant to the India's development story and if it follows these initiatives, they will also remain competitive and preferred choice in the banking landscape. .

\section{References}

1. http://www.businessworld.in/article/50-Of-Indians-Are-Associated-With-Cooperative-Banks/11-08-2017-123939/.

2. Dr. Vibha Bhilawadikar's Doctoral Thesis Impact of Impact Of "Personal Intervention" On Business Relationships In Banking Sector: A Case Study For Vishwas Cooperative Bank

3. Bhagwati Prasad. (December 2005, paper presented at the Round Table on Cooperative Banking held at CAB): Cooperative Banking in a Competitive Business Environment.

4. Ruth N Bolton (Vol 17 No1 1998 Marketing Science): In "A Dynamic Model of Duration of the customer relationship with a continuous service provider: The Role of Satisfaction": ISSN: 07322399.

5. Sanjay Kanti Das. (March 2012 published in Journal on Banking Financial Services \&Insurance Research Vol 3 Issue 2): Operational and Financial Performance Analysis of Meghalaya Cooperative Apex Bank: ISSN 2231-4288.

6. Gutek Barbara, A. Groth and Cherry Benneth (Volume 6, Issue 4, 2002 Academy of Management Perspectives) "Achieving service success through relationships and enhanced encounters".

7. Peter C. Verhoef (October 2003 Journal of Marketing Vol 67): Understanding the Effect of Customer Relationship Management Efforts on Customer Retention and Customer Share Development: ISSN:00222429.

8. https://www.fastcompany.com/28699/money-and-meaning-life By Michael S. Malonelong Read.

9. Roland. T. Rust, Tuck Sion Chung (Volume 25 Issue 6, November 2006 of Marketing Science: issn0732-2399 eissn1526-548X 062506 0560) Marketing Models of Service and Relationships.

10. Gutek Barbara, A. Groth and Cherry Benneth (Volume 6, Issue 4, 2002 Academy of Management Perspectives) "Achieving service success through relationships and enhanced encounters".

11. Thorsten Hennig-Thurau, Kevin P. Gwinner, Dwayne D. Gremler (Chapter 21: Why Customers Build Relationships with Companies - and Why Not): Relationship Marketing Gaining competitive advantage through customer satisfaction and Customer retention: ISBN3-540-66942-6.

12. https://www.nbrii.com/customer-survey-white-papers/measuring-and-managing-customer-satisfaction/.

13. Dr. Vibha Bhilawadikar's Doctoral Thesis Impact of Impact Of "Personal Intervention" On Business Relationships In Banking Sector: A Case Study For Vishwas Cooperative BANK.

14. https://www.marketingmag.com.au/hubs-c/banking-sector-challenges-fintech-disruption-falling-customer-experienceratings/.

15. https://blog.hubspot.com/service/customer-satisfaction-metrics. 